\title{
Role of Synaptophysin, Chromogranin and CD56 in adenocarcinoma and squamous cell carcinoma of the lung lacking morphological features of neuroendocrine differentiation: a retrospective large-scale study on 1170 tissue samples
}

Katharina Kriegsmann ${ }^{1}$, Christiane Zgorzelski ${ }^{2}$, Thomas Muley ${ }^{3,4}$, Petros Christopoulos ${ }^{4,5}$, Michael Thomas ${ }^{5}$, Hauke Winter ${ }^{3,4,6}$, Martin Eichhorn 3,4,6, Florian Eichhorn 3,4,6, Moritz von Winterfeld ${ }^{2}$, Esther Herpel ${ }^{2}$, Benjamin Goeppert ${ }^{2}$, Albrecht Stenzinger ${ }^{2,3}$, Felix J. F. Herth ${ }^{3,7}$, Arne Warth ${ }^{8}$ and Mark Kriegsmann ${ }^{2,34^{*}}$ (D)

\begin{abstract}
Background: Synaptophysin, chromogranin and CD56 are recommended markers to identify pulmonary tumors with neuroendocrine differentiation. Whether the expression of these markers in pulmonary adenocarcinoma and pulmonary squamous cell carcinoma is a prognostic factor has been a matter of debate. Therefore, we investigated retrospectively a large cohort to expand the data on the role of synaptophysin, chromogranin and CD56 in nonsmall cell lung cancer lacking morphological features of neuroendocrine differentiation.

Methods: A cohort of 627 pulmonary adenocarcinomas (ADC) and 543 squamous cell carcinomas (SqCC) lacking morphological features of neuroendocrine differentiation was assembled and a tissue microarray was constructed. All cases were stained with synaptophysin, chromogranin and CD56. Positivity was defined as $>1 \%$ positive tumor cells. Data was correlated with clinico-pathological features including overall and disease free survival.

Results: 110 (18\%) ADC and 80 (15\%) SqCC were positive for either synaptophysin, chromogranin, CD56 or a combination. The most commonly positive single marker was synaptophysin. The least common positive marker was chromogranin. A combination of $\leq 2$ neuroendocrine markers was positive in 2-3\% of ADC and 0-1\% of SqCC. There was no significant difference in overall survival in tumors with positivity for neuroendocrine markers neither in ADC (univariate: $P=0.4$; hazard ratio $[H R]=0.867$; multivariate: $P=0.5 ; \mathrm{HR}=0.876$ ) nor in SqCC (univariate: $P=0.1$; $H R=0.694$; multivariate: $P=0.1, H R=0.697$ ). Likewise, there was no significant difference in disease free survival. (Continued on next page)
\end{abstract}

\footnotetext{
* Correspondence: mark.kriegsmann@med.uni-heidelberg.de

${ }^{2}$ Institute of Pathology, University Hospital Heidelberg, Im Neuenheimer Feld 224, Heidelberg, Germany

${ }^{3}$ Translational Lung Research Centre Heidelberg, Member of the German Centre for Lung Research (DZL), Heidelberg, Germany

Full list of author information is available at the end of the article
}

(c) The Author(s). 2021 Open Access This article is licensed under a Creative Commons Attribution 4.0 International License, which permits use, sharing, adaptation, distribution and reproduction in any medium or format, as long as you give appropriate credit to the original author(s) and the source, provide a link to the Creative Commons licence, and indicate if changes were made. The images or other third party material in this article are included in the article's Creative Commons licence, unless indicated otherwise in a credit line to the material. If material is not included in the article's Creative Commons licence and your intended use is not permitted by statutory regulation or exceeds the permitted use, you will need to obtain permission directly from the copyright holder. To view a copy of this licence, visit http://creativecommons.org/licenses/by/4.0/ The Creative Commons Public Domain Dedication waiver (http://creativecommons.org/publicdomain/zero/1.0/) applies to the data made available in this article, unless otherwise stated in a credit line to the data. 
(Continued from previous page)

Conclusions: We report on a cohort of 1170 cases that synaptophysin, chromogranin and CD56 are commonly expressed in ADC and SqCC and that their expression has no impact on survival, supporting the current best practice guidelines.

Keywords: Synaptophysin, Chromogranin, CD56, Immunohistochemistry, Non-small cell lung cancer

\section{Background}

Synaptophysin, chromogranin and CD56 are recommended markers to identify pulmonary tumors with neuroendocrine differentiation [1]. These markers are frequently used to confirm a diagnosis of typical carcinoid, atypical carcinoid, small cell lung cancer and large cell neuroendocrine carcinoma (LCNEC). In the routine diagnostic setting, particularly the differentiation of LCNEC and pulmonary adenocarcinoma (ADC) with solid growth pattern or non-keratinizing squamous cell carcinoma (SqCC) might be challenging. According to current guidelines only non-small cell carcinomas (NSCLC) that exhibit morphological features of neuroendocrine differentiation should be stained with neuroendocrine markers. In case of a negative result these tumors should be labelled NSCLC with neuroendocrine morphology in biopsy specimens with a comment that the tumor is suspected to exhibit neuroendocrine differentiation that could not be confirmed by immunobiological staining. On the other hand, $\mathrm{ADC}$ and $\mathrm{SqCC}$ may show the expression of neuroendocrine markers despite the lack of neuroendocrine morphology. The clinical significance in this constellation has been investigated in previous studies [2-11]. While some of the studies suggested an impact of neuroendocrine marker expression on survival $[4,7,12-16]$ most of the studies reported no prediction of survival $[2,10,11]$. In this study we investigated over 1000 patient samples to expand the data on the role of synaptophysin, chromogranin and CD56 in NSCLC lacking morphological features of neuroendocrine differentiation.

\section{Methods}

\section{Patient cohort}

Formalin fixed and paraffin embedded NSCLC specimens resected from 2002 to 2010 in the Thoracic
Hospital Heidelberg at Heidelberg University were extracted from the archive of the Institute of Pathology, Heidelberg University, with the support of the tissue bank of the National Center for Tumour Diseases. Tissues were used in accordance with the ethical regulations of the NCT tissue bank defined by the local ethics committee (\#S315-2020, NCT\#2603). Diagnoses were made according to the recommendations of the 2015 world health classification of tumours of the lung, thymus and heart [1]. One thousand one hundred seventy patients with NSCLC including ADC and SqCC were selected. Tissue microarrays were constructed as described previously $[17,18]$.

\section{Immunohistochemistry}

Immunohistochemical (IHC) staining was performed as previously described $[18,19]$. In brief, slides were deparaffinized, pretreated with an antigen retrieval buffer and stained using an automated device. Immunohistochemical stainings were performed on a Ventana Benchmark Ultra (Roche, Switzerland). The antibody and staining conditions are shown in Table 1 . The evaluation was carried out by an experienced pathologist (MK). Synaptophysin and chromogranin were considered when located in the cytoplasm, CD56 was evaluated when located on the membrane. Positivity of a marker was defined as $>1 \%$ positive tumor cells, as in previous studies [2]. Typical examples of positive and negative staining results of $\mathrm{ADC}$ and $\mathrm{SqCC}$ are shown in Figs. 1 and 2. The results from the conventional NSCLC markers TTF-1 and p40 were published previously [20, 21].

\section{Molecular data}

Molecular data included results for KRAS, EGFR, BRAF, ROS1 and ALK testing were available for ADC from a previous investigation [22]. In brief, cases were analyzed

Table 1 Antibodies used and staining conditions

\begin{tabular}{|c|c|c|c|c|c|c|}
\hline Antibody & Company & Clone & Pretreatment & Buffer incubation time (min) & Antibody incubation time (min) & Dilution \\
\hline p40 & Ventana & BC28 & Tris/Borat/ EDTA, pH 8.4 & 48 & 24 & RTU \\
\hline TTF-1 & Novocastra & SPT24 & Tris/Borat/ EDTA, pH 8.4 & 56 & 24 & $1: 100$ \\
\hline Synaptophysin & Cell Marque & MRQ-40 & Tris/Borat/ EDTA, pH 8.4 & 48 & 24 & RTU \\
\hline Chromogranin A & Dako & polyclonal & Tris/Borat/ EDTA, pH 8.4 & 32 & 24 & 1:400 \\
\hline CD56 & Ventana & MRQ-42 & Tris/Borat/ EDTA, pH 8.4 & 40 & 24 & RTU \\
\hline
\end{tabular}

$C D$ cluster of differentiation, TTF-1 thyroid transcription factor 1 

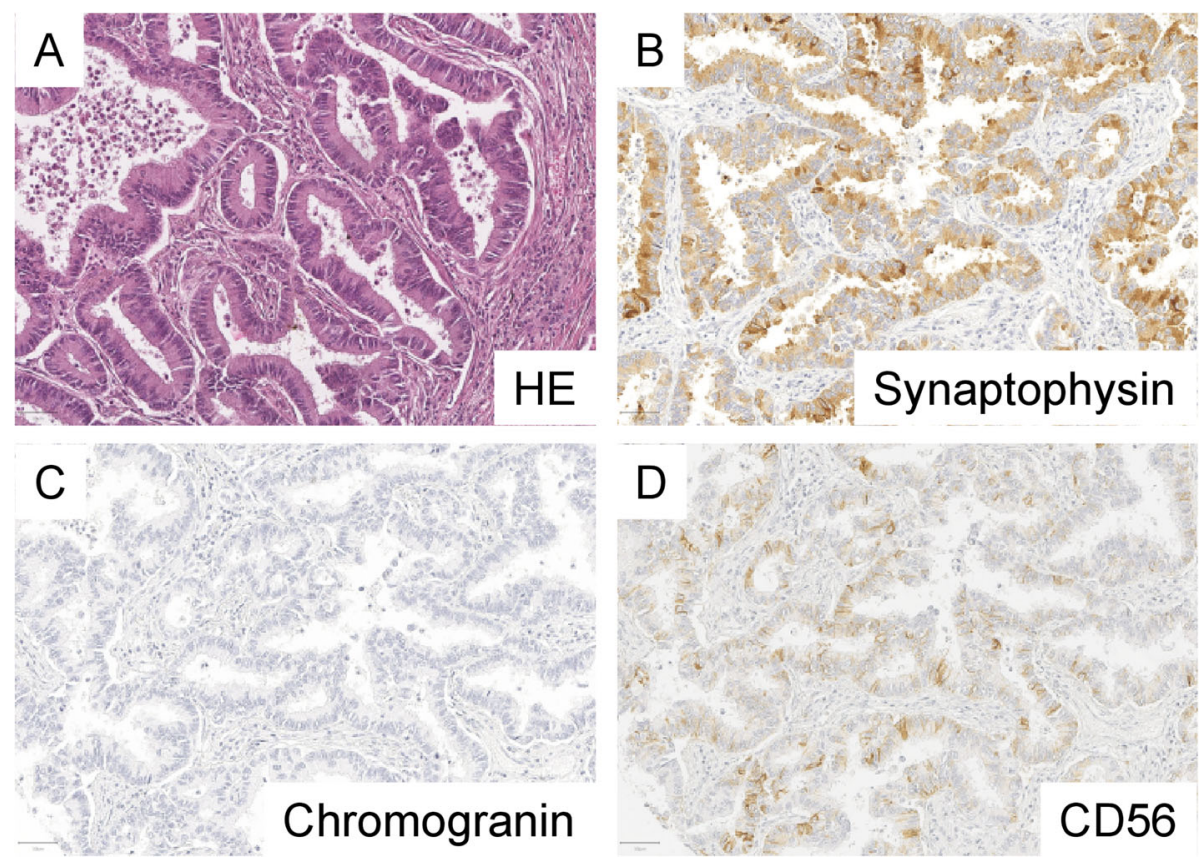

Fig. 1 Example of a pulmonary adenocarcinoma positive for neuroendocrine markers. The typical acinar growth pattern of pulmonary adenocarcinoma is seen (a, HE, 200x). Synaptophysin shows homogenous moderate to strong positivity (b, Synaptophysin, 200x). Chromogranin is negative (c, Chromogranin, 200x). CD56 shows focal moderate positivity (d, CD56, 200x)
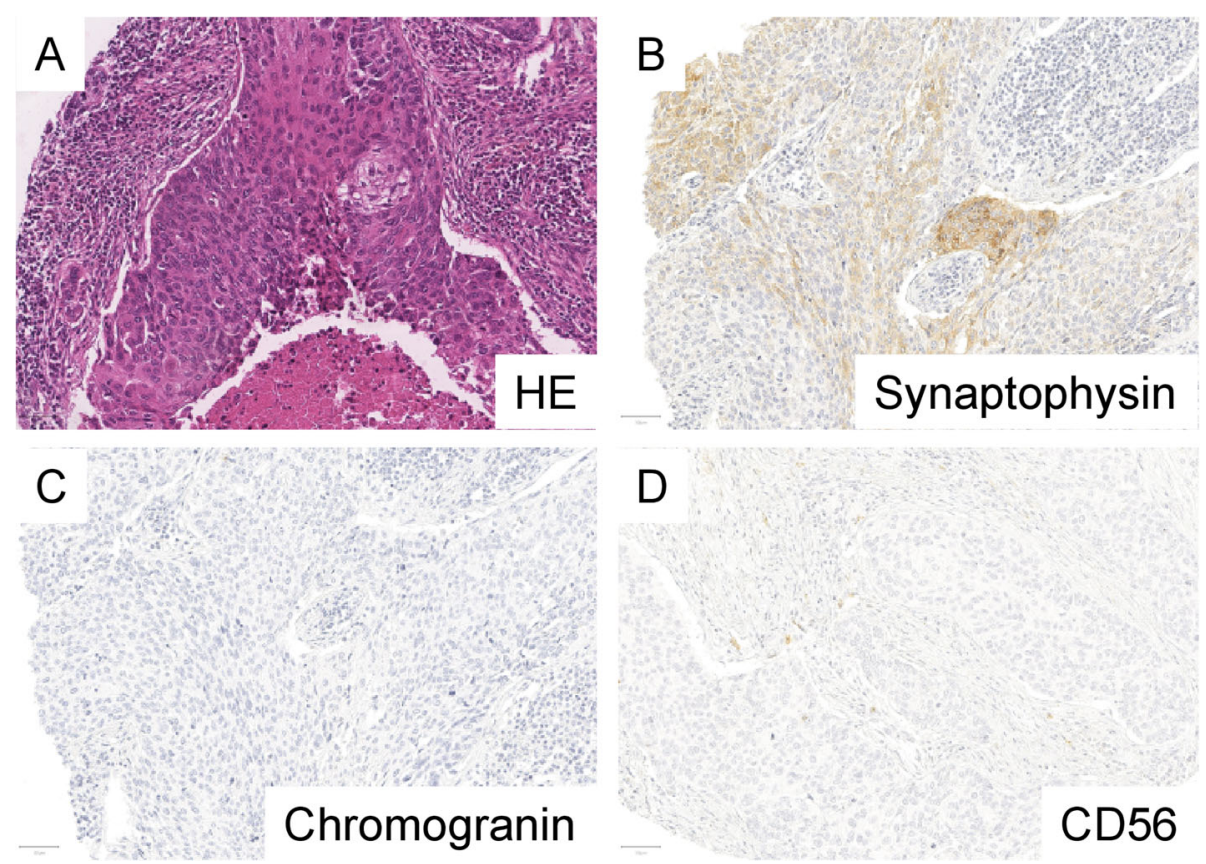

Fig. 2 Example of a pulmonary squamous cell carcinoma positive for neuroendocrine markers. Typical morphological features of squamous cell carcinoma with local dyskeratosis is seen (a, HE, 200x). Synaptophysin shows focal moderate positivity (b, Synaptophysin, 200x). Chromogranin and CD56 are negative in this example (c, Chromogranin, d, CD56, 200x) 
by Sanger sequencing for KRAS (exon 1), EGFR (exons 18-21) and BRAF (exon 15). Cases tested for ROS1 and $A L K$ were prescreen using IHC, results were subsequently validated by fluorescence in situ hybridization (FISH) using a break-apart probe. Only cases with FISHconfirmation were considered positive.

\section{Data analysis}

Statistical analyses were performed using R-Statistical Software (www.r-project.org, v.4.0.0, Free Software Foundation), R-Studio (v. 1.2.5042, Affero General Public License, USA), or Excel 2019 (Microsoft, USA). Correlation of the immunohistochemical stains with clinicopathological characteristics was by the unpaired $t$-test for numerical and by the Fisher-Freeman-Halton test for categorical variables. Analysis of overall survival (OS), disease-free survival (DFS) and Kaplan-Meier plots were done with the survival and the survminer package in R. In the multivariate Cox regression model no model selection procedures were applied as we aimed to fit a model with all, from the clinical/diagnostic point of few, main effects and also show the missing impact of statistically not significant variables. $P$-values $<0.05$ were considered significant.

\section{Results}

\section{Patient characteristics}

Overall, 1170 NSCLC including 627 ADC and 543 SqCC were analyzed. $816(70 \%)$ patients were male, $354(30 \%)$ were female. Median age was 64 years (min-max: 30-89 years). Most patients underwent surgery with pT2 tumors and negative lymph-node status.

\section{Expression of p40, TTF-1, Synaptophysin, Chromogranin and CD56}

$548(87 \%)$ ADC were positive with antibodies against TTF-1. Only 8 (1\%) ADC showed positivity against p40.
Table $2 \mathrm{IHC}$ staining characteristics of ADC and SqCC tumors

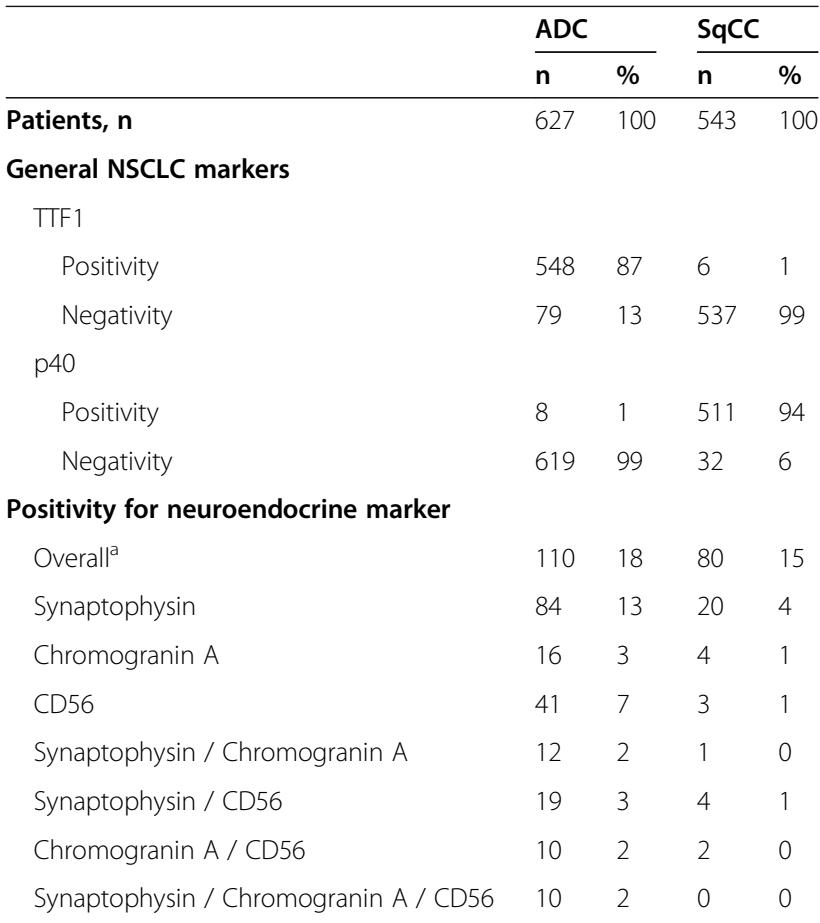

$A D C$ adenocarcinoma, IHC immunohistochemistry, NSCLC non-small cell lung carcinoma, $\mathrm{SqCC}$ squamous cell carcinoma

${ }^{a}$ Overall positivity was defined as positivity for $\geq 1$ neuroendocrine marker

These cases also exhibited positivity for TTF-1 in the same tumor cells and showed a typical growth pattern of adenocarcinoma. The vast majority of ADC were negative for p40 (99\%). 511 (94\%) SqCC were positive with antibodies against p40. Only 6 (1\%) SqCC exhibited focal weak TTF-1 positivity. These tumors showed keratinization and intercellular bridges and were therefore classified as SqCC. The majority of SqCC were negative for TTF-1 (99\%). None of the ADC and SqCC

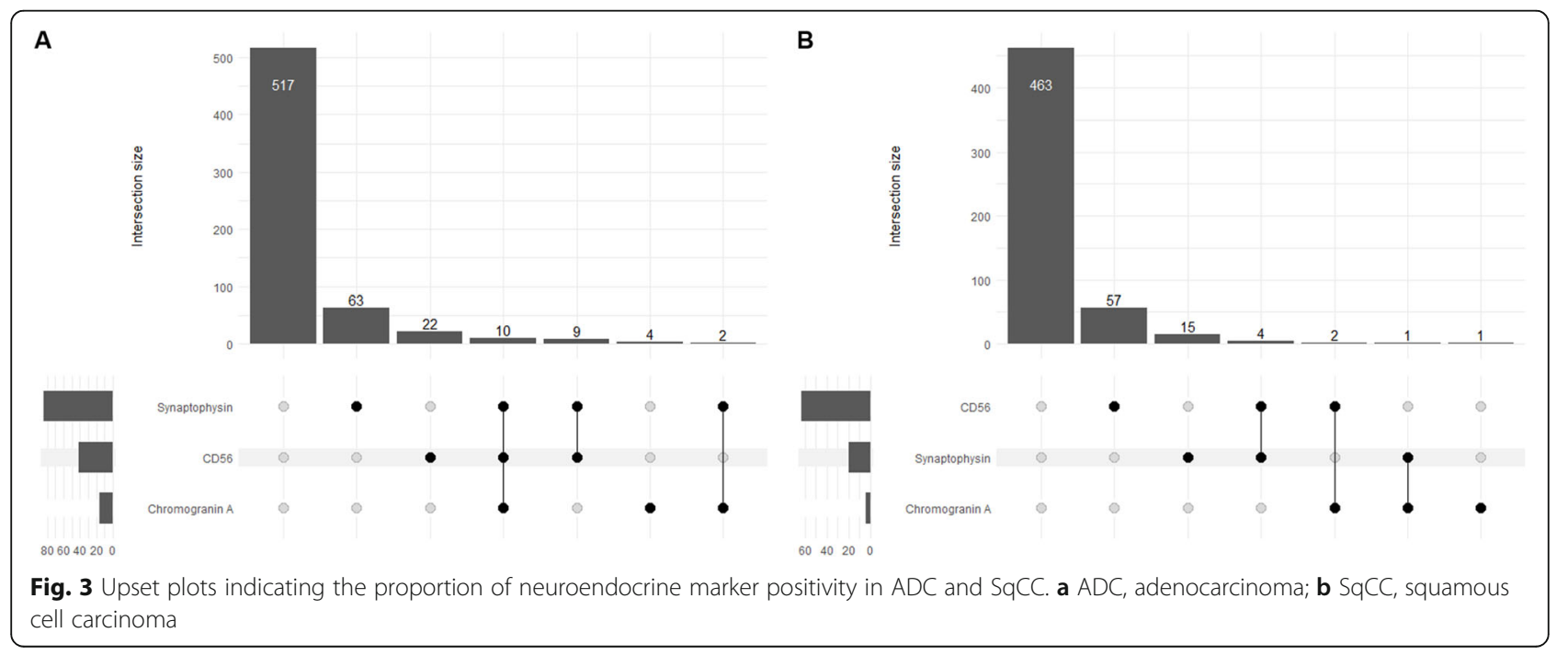


Table 3 ADC patient characteristics and stratification by neuroendocrine marker

\begin{tabular}{|c|c|c|c|c|c|c|c|}
\hline & ADC overa & hort & $A D C$ neuro & arker positive & ADC neuro & rker negative & $p$ value \\
\hline & $\bar{n}$ & $\%$ & $\mathrm{n}$ & $\%$ & $\mathrm{n}$ & $\%$ & \\
\hline Patients & 627 & 100 & 110 & 100 & 517 & 100 & \\
\hline Gender & & & & & & & \\
\hline Male & 365 & 58 & 67 & 61 & 298 & 58 & 0.528 \\
\hline Female & 262 & 42 & 43 & 39 & 219 & 42 & \\
\hline Age, median y (range) & $63(30-89)$ & & $63(41-84)$ & & $63(30-89)$ & & 0.373 \\
\hline TNM & & & & & & & \\
\hline pT & & & & & & & \\
\hline pT1 & 127 & 20 & 25 & 23 & 102 & 20 & 0.535 \\
\hline pT2 & 388 & 62 & 63 & 57 & 325 & 63 & \\
\hline pT3 & 94 & 15 & 17 & 15 & 77 & 15 & \\
\hline pT4 & 18 & 3 & 5 & 5 & 13 & 3 & \\
\hline $\mathrm{pN}$ & & & & & & & \\
\hline pNO & 314 & 50 & 63 & 57 & 251 & 49 & $0.068^{\mathrm{a}}$ \\
\hline $\mathrm{pN} 1$ & 94 & 15 & 14 & 13 & 80 & 15 & \\
\hline $\mathrm{pN} 2$ & 192 & 31 & 28 & 25 & 164 & 32 & \\
\hline $\mathrm{pN} 3$ & 5 & 1 & 0 & 0 & 5 & 1 & \\
\hline $\mathrm{pNX}$ & 22 & 4 & 5 & 5 & 17 & 3 & \\
\hline $\mathrm{pM}$ & & & & & & & \\
\hline pM1 & 26 & 4 & 2 & 2 & 24 & 5 & \\
\hline $\mathrm{pMX}$ & 601 & 96 & 108 & 98 & 493 & 95 & \\
\hline Stage & & & & & & & \\
\hline 1 & 254 & 41 & 46 & 42 & 208 & 40 & $0.153^{\mathrm{b}}$ \\
\hline$\|$ & 130 & 21 & 29 & 26 & 101 & 20 & \\
\hline III & 217 & 35 & 33 & 30 & 184 & 36 & \\
\hline IV & 26 & 4 & 2 & 2 & 24 & 5 & \\
\hline Genetic aberrations & & & & & & & \\
\hline KRAS & $147^{c}$ & 36 & $29^{d}$ & 36 & $118^{e}$ & 36 & $0.732^{f}$ \\
\hline EGFR & $64^{c}$ & 16 & $10^{d}$ & 8 & 52 & 16 & \\
\hline BRAF & $14^{c}$ & 3 & $2^{d}$ & 3 & 12 & 4 & \\
\hline ROS1 & $5^{c}$ & 1 & $1^{d}$ & 1 & 4 & 1 & \\
\hline ALK & $5^{c}$ & 1 & $0^{\mathrm{d}}$ & 0 & 5 & 2 & \\
\hline
\end{tabular}

$A D C$ adenocarcinoma, $M$ metastases, $N$ nodal stage, $T$ tumor size, $y$ year

a $\mathrm{pN} 0$ versus $\mathrm{pN} 1 / \mathrm{pN} 2 / \mathrm{pN} 3$; $\mathrm{pNX}$ not included

${ }^{b}$ stage I versus II versus III/IV

cavailable for 405 cases

available for 80 cases

available for 327 cases

fKRAS versus EGFR versus BRAF/ROS1/ALK

showed morphological features of neuroendocrine differentiation.

Overall, 110 (18\%) ADC and 80 (15\%) SqCC were positive for either synaptophysin, chromogranin, CD56 or a combination of these. The most commonly positive single marker was synaptophysin in ADC (13\%) and SqCC (4\%). The least common positive marker was chromogranin in ADC (3\%) and CD56 in SqCC (1\%). A combination of either two or three neuroendocrine markers was positive in $2-3 \%$ of $\mathrm{ADC}$ and $0-1 \%$ of SqCC. A summary of the expression of p40, TTF-1 and the neuroendocrine markers is provided in Table 2 and Fig. 3. No significant difference of gender, age, T- and
$\mathrm{N}$-categories as well as clinical stage were observed between ADC and SqCC with and without expression of neuroendocrine markers (Tables 3 and 4).

\section{Survival analysis}

OS was analyzed in patients with ADC and SqCC with respect to the expression of neuroendocrine markers. Although survival in ADC and SqCC with expression of neuroendocrine marker expression was better, but no significant difference was detected in univariate OS analysis in $\operatorname{ADC}(P=0.4$; hazard ratio $[\mathrm{HR}]=0.867 ; 95 \%$ confidence interval [CI95 $=0.622-1.207]$ ) and SqCC $(P=0.1 ;$ HR $=0.694 \quad[$ CI95 $=0.462-1.042]$. Likewise, no 
Table 4 SqCC patient characteristics and stratification by neuroendocrine marker

\begin{tabular}{|c|c|c|c|c|c|c|c|}
\hline & \multicolumn{2}{|c|}{ SqCC overall cohort } & \multicolumn{2}{|c|}{ SqCC neuroendocrine marker positive } & \multicolumn{2}{|c|}{ SqCC neuroendocrine marker negative } & \multirow[t]{2}{*}{$p$ value } \\
\hline & $\mathrm{n}$ & $\%$ & $\mathrm{n}$ & $\%$ & $\mathrm{n}$ & $\%$ & \\
\hline Patients & 543 & 100 & 80 & 100 & 463 & & \\
\hline \multicolumn{8}{|l|}{ Gender } \\
\hline Male & 451 & 83 & 67 & 84 & 384 & 83 & \multirow[t]{2}{*}{0.858} \\
\hline Female & 92 & 17 & 13 & 16 & 79 & 17 & \\
\hline Age, median y (range) & \multicolumn{2}{|l|}{$65(38-83)$} & \multicolumn{2}{|l|}{$64(40-82)$} & \multicolumn{2}{|l|}{$65(38-83)$} & 0.428 \\
\hline \multicolumn{8}{|l|}{ TNM } \\
\hline \multicolumn{8}{|l|}{ pT } \\
\hline pT1 & 106 & 20 & 16 & 20 & 90 & 19 & \multirow[t]{4}{*}{0.645} \\
\hline pT2 & 324 & 60 & 48 & 60 & 276 & 60 & \\
\hline pT3 & 93 & 17 & 15 & 19 & 78 & 17 & \\
\hline pT4 & 20 & 4 & 1 & 1 & 19 & 4 & \\
\hline \multicolumn{8}{|l|}{$\mathrm{pN}$} \\
\hline pNO & 255 & 47 & 35 & 44 & 220 & 48 & \multirow[t]{5}{*}{0.570} \\
\hline $\mathrm{pN} 1$ & 179 & 33 & 23 & 29 & 156 & 34 & \\
\hline pN2 & 98 & 18 & 20 & 25 & 78 & 17 & \\
\hline pN3 & 1 & 0 & 0 & 0 & 1 & 0 & \\
\hline pNX & 10 & 2 & 2 & 3 & 8 & 2 & \\
\hline \multicolumn{8}{|l|}{$\mathrm{pM}$} \\
\hline pM1 & 8 & 1 & 2 & 3 & 6 & 1 & \\
\hline pMX & 535 & 99 & 78 & 98 & 457 & 99 & \\
\hline \multicolumn{8}{|l|}{ Stage } \\
\hline 1 & 185 & 34 & 28 & 35 & 157 & 34 & \multirow[t]{4}{*}{0.437} \\
\hline$\|$ & 208 & 38 & 26 & 33 & 182 & 39 & \\
\hline III & 142 & 26 & 24 & 30 & 118 & 25 & \\
\hline IV & 8 & 1 & 2 & 3 & 6 & 1 & \\
\hline
\end{tabular}

$M$ metastases, $N$ nodal stage, $S q C C$ squamous cell carcinoma, $T$ tumor size, $y$ year a pNO versus $\mathrm{pN} 1 / \mathrm{pN} 2 / \mathrm{pN} 3$; pNX not included

${ }^{b}$ stage I versus II versus III/IV

significant difference was detected in univariate DFS in ADC $\quad(P=0.4 ; \quad H R=1.136 ; \quad C I 95=0.832-1.136) \quad$ and SqCC $(P=0.3$; CI95 $=0.448-1.260)$. Kaplan-Meier plots are shown in Figs. 4 and 5.

Multivariate Cox-proportional hazard analysis for OS showed a significant impact of clinical stage and gender in ADC, but only of clinical stage in SqCC. No significance of neuroendocrine marker expression was detected for $\mathrm{ADC}$ and SqCC regarding $\mathrm{OS}$ in multivariate analysis (Tables 5 and 6).

\section{Discussion}

In the present study we investigated the impact of the expression of synaptophysin, chromogranin and CD56 in $\mathrm{ADC}$ and $\mathrm{SqCC}$ without neuroendocrine morphology on overall survival in a large study including more than

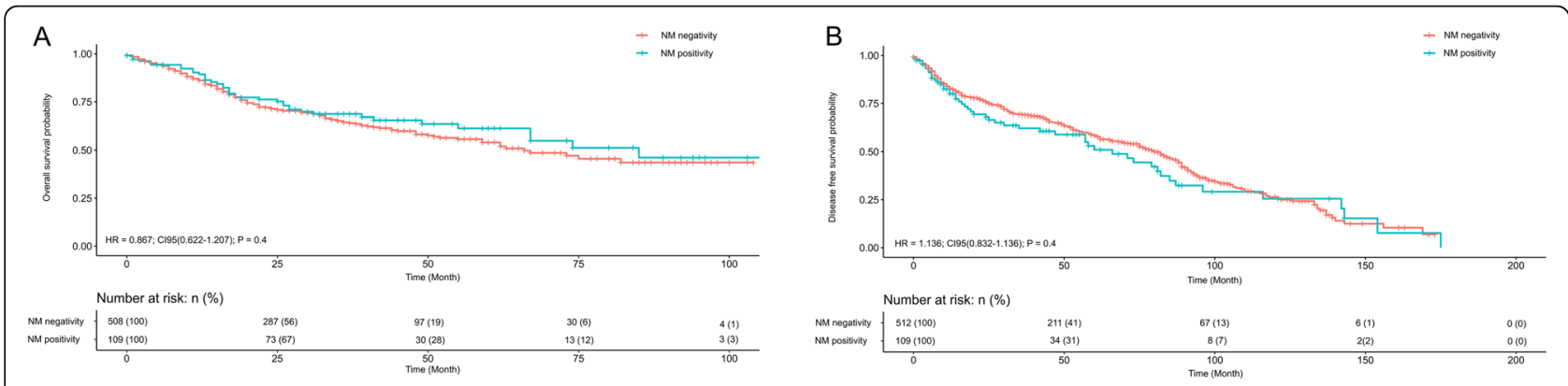

Fig. 4 Univariate OS and DFS analysis of ADC cases with regard to positivity and negativity of neuroendocrine marker. Overall positivity was defined as positivity for $\geq 1$ neuroendocrine marker. NM, neuroendocrine marker; OS, overall survival 

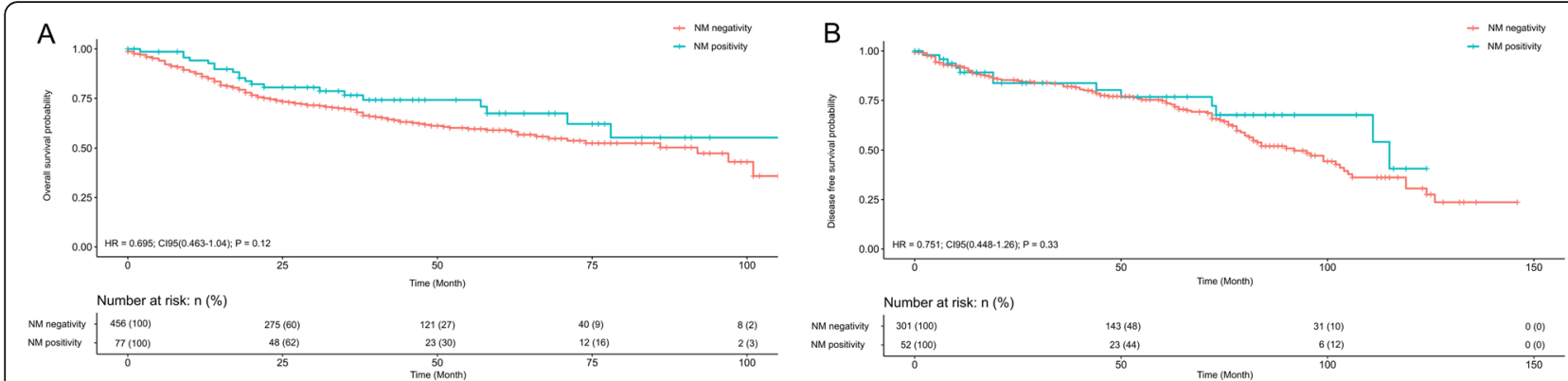

Fig. 5 Univariate OS and DFS analysis of SqCC cases with regard to positivity and negativity of neuroendocrine marker. Overall positivity was defined as positivity for $\geq 1$ neuroendocrine marker. NM, neuroendocrine marker; OS, overall survival

1000 patients. This is the largest cohort reported on this topic to date. We found that neuroendocrine marker expression is common and is not associated with OS and DFS.

Staining a combination of synaptophysin, chromogranin and CD56 is currently advised to establish evidence of neuroendocrine differentiation in thoracic tumors [23]. However, staining should be restricted to NSCLC exhibiting neuroendocrine differentiation, as it has been shown that $\mathrm{ADC}$ and SqCC may exhibit positive staining in $10-30 \%$ in most studies $[2,6]$. Studies reporting a higher positivity rate were commonly done on whole slides [3] and not on tissue micro-arrays [2, 4, 11], with one exception reporting neuroendocrine marker expression in up to $90 \%$ of tumors [5]. Thus, our results are in line with the literature $[3,6,10]$. The differences of the reported positivity rates might also be explained by different cut-offs for the definition of positivity and the application of different antibody clones [5, 10, 11]. We investigated only one cut-off value for positivity and choose a cut-off of $>1 \%$ positive tumor cells. This cut-

Table 5 Multivariate Cox proportional hazard analysis for OS in ADC

\begin{tabular}{lll}
\hline Variable & HR $\left(\mathbf{C l}_{\mathbf{9 5}}\right)$ & $\boldsymbol{p}$ value \\
\hline Stage II & 2.76 & $<$ \\
& $(1.576-3.581)$ & $\mathbf{0 . 0 0 \mathbf { 1 } ^ { \mathbf { a } }}$ \\
Stage III & 4.649 & $<$ \\
& $(3.276-6.597)$ & $\mathbf{0 . 0 0 \mathbf { 1 } ^ { \mathbf { a } }}$ \\
Stage IV & 6.729 & $<$ \\
& $(3.726-12.155)$ & $\mathbf{0 . 0 0 \mathbf { 1 } ^ { \mathbf { a } }}$ \\
Age (> 59 versus < 59 years) & 1.036 & 0.809 \\
& $(0.776-1.384)$ & \\
Gender (female versus male) & 0.564 & $<\mathbf{0 . 0 0 1}$ \\
& $(0.420-0.757)$ & \\
Neuroendocrine marker (positivity versus & 0.876 & 0.463 \\
negativity) & $(0.616-1.247)$ & \\
\hline
\end{tabular}

$n=617$

a as compared to Stage I

OS overall survival off has been used in other previous studies but is somewhat arbitrary [2,3]. We decided to use this cut-off as single cell positivity is a physiologic finding in lung tissue and single neuroendocrine cells overgrown by tumor cells and unspecific background staining might not be reliably distinguished from positive tumor cells [24]. Moreover, cut-off values above $1 \%$ are rarely helpful in the routine diagnostic setting. Ionescu et al. reported CD56 to be most commonly expressed closely followed by synaptophysin [2], while Sterlacci et al. reported synaptophysin to be the most commonly detected positive marker in ADC and SqCC, as in our study [11]. In line with these large-scale investigations, chromogranin was least commonly expressed in our study.

The impact of neuroendocrine marker expression on survival of patients with ADC and SqCC is controversially discussed. While most investigations found no impact on prognosis, some more recent studies challenged this finding $[4,25,26]$. Feng et al. investigated the impact of neuroendocrine marker expression on OS and DFS in one of the largest cohorts including a total of 451 patients and found a significantly worse survival in patients with tumors expressing neuroendocrine markers [4]. However, another large study including more than $200 \mathrm{ADC}$ and SqCC did not find any prognostic impact neither on OS nor DFS, in line with the findings of our study [2].

Another marker of neuroendocrine differentiation, Insulinoma-associated Protein 1 (INSM1), has been reported to support the diagnosis of neuroendocrine differentiation in thoracic tumors and has the potential to complement the currently recommended neuroendocrine markers [27, 28]. Interestingly, INSM1 has been reported to be more sensitive and specific as compared to the single markers Synaptophysin, Chromogranin and CD56 and was therefore advocated as a first-line stand alone marker or in combination with CD56 to detect neuroendocrine differentiation [28-31]. INSM1 marker expression 
Table 6 Multivariate Cox proportional hazard analysis for OS in SqCC

\begin{tabular}{lll}
\hline Variable & $\mathbf{H R}\left(\mathbf{C l}_{\mathbf{9 5}}\right)$ & $\boldsymbol{p}$ value \\
\hline Stage II & 1.657 & $\mathbf{0 . 0 0 \mathbf { 9 } ^ { \mathbf { a } }}$ \\
& $(1.135-2.419)$ & \\
Stage III & 2.889 & $<$ \\
& $(1.954-4.274)$ & $\mathbf{0 . 0 0 \mathbf { 1 } ^ { \mathbf { a } }}$ \\
Stage IV & 4.205 & $\mathbf{0 . 0 1 7 ^ { \mathbf { a } }}$ \\
& $(1.298-13.624)$ & \\
Age (> 59 versus <59 years) & 1.282 & 0.168 \\
& $(0.900-1.826)$ & \\
Gender (female versus male) & 0.790 & 0.305 \\
& $(0.504-1.239)$ & \\
Neuroendocrine marker (positivity versus & 0.697 & 0.131 \\
negativity) & $(0.436-1.113)$ & \\
\hline
\end{tabular}

$n=533$

OS overall survival

a as compared to Stage I

has been suggested to be prognostic in high-grade neuroendocrine neoplasms, but if INSM1 expression has a prognostic impact in $\mathrm{ADC}$ or SqCC remains to be investigated [32].

Moreover, we could not detect any differences in the rate of common genetic aberrations in pulmonary ADC when we compared tumors with and without expression of neuroendocrine markers. Although we analyzed a large cohort, these data must be interpreted with caution, because the respective patient subsets were small.

Our study has several limitations: first, the retrospective design of the investigation. Prospective large-scale studies are not available to the best of our knowledge. Second, we used a tissue microarray as a surrogate for the biopsy situation. As only two cores from the whole tumor were investigated, it is not entirely clear if other parts of tumors that were judged negative in our study exhibit neuroendocrine immunoreactivity. This problem is also highlighted by the fact that previous studies on whole slides reported higher rates of neuroendocrine positivity [3]. On the other hand numerous studies comparing the results of tissue microarray studies with the findings from conventional large sections using other biomarkers have shown that all well-established associations between molecular markers and tumor phenotype or patient prognosis can be reproduced with tissue microarrays [33].

\section{Conclusion}

In summary, we show that synaptophysin, chromogranin and CD56 are commonly expressed in ADC and SqCC and that their expression as no impact on OS and DFS supporting the current best practice guidelines.

\section{Abbreviations}

ADC: Adenocarcinoma; CD: Cluster of differentiation; DFS: Disease-free survival; FISH: Fluorescence in situ hybridization; IHC: Immunohistochemistry; INSM1: Insulinoma-associated Protein 1; LCNEC: Large cell neuroendocrine carcinoma; NSCLC: Non-small cell lung cancer; OS: Overall survival; SqCC: Squamous cell carcinoma

\section{Acknowledgements \\ None.}

Authors' contributions

Design of the study: KK, MK, AW. Construction of TMA: CZ, TM, HW, AW. Contribution of clinical data: TM, CP, MT, HW, ME, FE, FH. Evaluation of IHC staining: MK. Diagnosis: MW, EH, BG, AS, AW, MK. Data analysis: KK, MK. Draft: KK, MK. Review of the manuscript: all authors. The author(s) read and approved the final manuscript.

\section{Funding}

The study has been self-funded. Open Access funding enabled and organized by Projekt DEAL.

\section{Availability of data and materials}

The datasets used and/or analyzed during the current study are available from the corresponding author on reasonable request.

\section{Declarations}

Ethics approval and consent to participate

Ethics approval has been obtained from the ethics committee of the University Heidelberg (\#S315-2020). Consent to participate has been given by all patients.

\section{Consent for publication \\ Not applicable.}

\section{Competing interests}

There are no competing interests.

\section{Author details}

${ }^{1}$ Department of Hematology, Oncology and Rheumatology, University Hospital Heidelberg, Heidelberg, Germany. ${ }^{2}$ Institute of Pathology, University Hospital Heidelberg, Im Neuenheimer Feld 224, Heidelberg, Germany. ${ }^{3}$ Translational Lung Research Centre Heidelberg, Member of the German Centre for Lung Research (DZL), Heidelberg, Germany. ${ }^{4}$ Translational Research Unit, Thoraxklinik at Heidelberg University, Heidelberg, Germany. ${ }^{5}$ Department of Thoracic Oncology, Thoraxklinik at Heidelberg University, Heidelberg, Germany. 'Department of Thoracic Surgery, Thoraxklinik at Heidelberg University, Heidelberg, Germany. ${ }^{7}$ Department of Pneumology and Critical Care Medicine, Thoraxklinik at Heidelberg University, Heidelberg, Germany. ${ }^{8}$ Institute of Pathology, Cytopathology, and Molecular Pathology, UEGP MVZ, Gießen, Wetzlar, Limburg, Germany.

Received: 7 June 2020 Accepted: 2 April 2021

Published online: 01 May 2021

\section{References}

1. Travis WD, Brambilla E, Nicholson AG, Yatabe Y, Austin JHM, Beasley MB, et al. The 2015 World Health Organization classification of lung tumors: impact of genetic, clinical and radiologic advances since the 2004 classification. J Thorac Oncol. 2015;10(9):1243-60. https://doi.org/10.1097/ JTO.0000000000000630.

2. Ionescu DN, Treaba D, Gilks CB, Leung S, Renouf D, Laskin J, et al. Nonsmall cell lung carcinoma with neuroendocrine differentiation--an entity of no clinical or prognostic significance. Am J Surg Pathol. 2007;31(1):26-32. https://doi.org/10.1097/01.pas.0000213319.04919.97.

3. Howe MC, Chapman A, Kerr K, Dougal M, Anderson H, Hasleton PS. Neuroendocrine differentiation in non-small cell lung cancer and its relation to prognosis and therapy. Histopathology. 2005;46(2):195-201. https://doi. org/10.1111/j.1365-2559.2005.02047.x.

4. Feng J, Sheng H, Zhu C, Qian X, Wan D, Su D, et al. Correlation of neuroendocrine features with prognosis of non-small cell lung cancer. 
Oncotarget. 2016;7(44):71727-36. https://doi.org/10.18632/oncota rget.12327.

5. Gottschling S, Jensen K, Herth FJ, Thomas M, Schnabel PA, Herpel E. Lack of prognostic significance of neuroendocrine differentiation and stem cell antigen co-expression in resected early-stage non-small cell lung cancer. Anticancer Res. 2013;33(3):981-90.

6. Harada M, Yokose T, Yoshida J, Nishiwaki Y, Nagai K. Immunohistochemical neuroendocrine differentiation is an independent prognostic factor in surgically resected large cell carcinoma of the lung. Lung Cancer. 2002; 38(2):177-84. https://doi.org/10.1016/S0169-5002(02)00181-2.

7. Graziano SL, Tatum AH, Newman NB, Oler A, Kohman LJ, Veit LJ, et al. The prognostic significance of neuroendocrine markers and carcinoembryonic antigen in patients with resected stage I and II non-small cell lung cancer. Cancer Res. 1994;54(11):2908-13.

8. Slodkowska J, Zych J, Szturmowicz M, Demkow U, Rowinska-Zakrzewska E, Roszkowski-Sliz K. Neuroendocrine phenotype of non-small cell lung carcinoma: immunohistological evaluation and biochemical study. Int J Biol Markers. 2005;20(4):217-26. https://doi.org/10.1177/172460080502000404.

9. Linnoila RI, Piantadosi S, Ruckdeschel JC. Impact of neuroendocrine differentiation in non-small cell lung cancer. The LCSG experience. Chest. 1994;106(6 Suppl):367S-71S.

10. Carnaghi C, Rimassa L, Garassino I, Santoro A. Clinical significance of neuroendocrine phenotype in non-small-cell lung cancer. Ann Oncol. 2001; 12(Suppl 2):S119-23. https://doi.org/10.1093/annonc/12.suppl_2.S119.

11. Sterlacci W, Fiegl M, Hilbe W, Auberger J, Mikuz G, Tzankov A. Clinical relevance of neuroendocrine differentiation in non-small cell lung cancer assessed by immunohistochemistry: a retrospective study on 405 surgically resected cases. Virchows Arch. 2009;455(2):125-32. https://doi.org/10.1007/ s00428-009-0812-0.

12. Schleusener JT, Tazelaar HD, Jung SH, Cha SS, Cera PJ, Myers JL, et al. Neuroendocrine differentiation is an independent prognostic factor in chemotherapy-treated nonsmall cell lung carcinoma. Cancer. 1996;77(7): 1284-91. https://doi.org/10.1002/(SICl)1097-0142(19960401)77:7<1284::AIDCNCR9>3.0.CO;2-1.

13. Carles J, Rosell R, Ariza A, Pellicer I, Sanchez JJ, Fernandez-Vasalo G, et al. Neuroendocrine differentiation as a prognostic factor in non-small cell lung cancer. Lung Cancer. 1993;10(3-4):209-19. https://doi.org/10.1016/01695002(93)90181-V.

14. Kowalski DM, Krzakowski M, Jaskiewicz P, Olszewski W, Janowicz-Zebrowska A, Wojas-Krawczyk K, et al. Prognostic value of synaptophysin and chromogranin a expression in patients receiving palliative chemotherapy for advanced non-small-cell lung cancer. Respiration. 2013;85(4):289-96. https:// doi.org/10.1159/000337090

15. Petrovic M, Baskic D, Bankovic D, llic N. Neuroendocrine differentiation as an indicator of chemosensitivity and prognosis in nonsmall cell lung cancer. Biomarkers. 2011;16(4):311-20. https://doi.org/10.3109/1354750X.2011.5602 81.

16. Gajra A, Tatum AH, Newman N, Gamble GP, Lichtenstein S, Rooney MT, et al. The predictive value of neuroendocrine markers and p53 for response to chemotherapy and survival in patients with advanced non-small cell lung cancer. Lung Cancer. 2002;36(2):159-65. https://doi.org/10.1016/501695002(01)00463-9.

17. Kazdal $D$, Endris V, Allgauer M, Kriegsmann M, Leichsenring J, Volckmar AL, et al. Spatial and temporal heterogeneity of panel-based tumor mutational burden (TMB) in pulmonary adenocarcinoma: separating biology from technical artifacts. J Thorac Oncol. 2019;14(11):1935-47. https://doi.org/10.1 016/j.jtho.2019.07.006.

18. Kriegsmann M, Muley T, Harms A, Tavernar L, Goldmann T, Dienemann H, et al. Differential diagnostic value of CD5 and CD117 expression in thoracic tumors: a large scale study of 1465 non-small cell lung cancer cases. Diagn Pathol. 2015;10(1):210. https://doi.org/10.1186/s13000-015-0441-7.

19. Ly A, Longuespee R, Casadonte R, Wandernoth P, Schwamborn K, Bollwein $C$, et al. Site-to-site reproducibility and spatial resolution in MALDI-MSI of peptides from formalin-fixed paraffin-embedded samples. Proteomics Clin Appl. 2019;13(1):e1800029. https://doi.org/10.1002/prca.201800029.

20. Warth A, Muley T, Herpel E, Meister M, Herth FJ, Schirmacher P, et al. Largescale comparative analyses of immunomarkers for diagnostic subtyping of non-small-cell lung cancer biopsies. Histopathology. 2012;61 (6):1017-25. https://doi.org/10.1111/j.1365-2559.2012.04308.x.

21. Kriegsmann K, Cremer M, Zgorzelski C, Harms A, Muley T, Winter H, et al. Agreement of CK5/6, p40, and p63 immunoreactivity in non-small cell lung cancer. Pathology. 2019;51(3):240-5. https://doi.org/10.1016/j.pathol.2018.11. 009.

22. Warth A, Penzel R, Lindenmaier $H$, Brandt $R$, Stenzinger $A$, Herpel $E$, et al. EGFR, KRAS, BRAF and ALK gene alterations in lung adenocarcinomas: patient outcome, interplay with morphology and immunophenotype. Eur Respir J. 2014;43(3):872-83. https://doi.org/10.1183/09031936.00018013.

23. Yatabe Y, Dacic S, Borczuk AC, Warth A, Russell PA, Lantuejoul S, et al. Best practices recommendations for diagnostic immunohistochemistry in lung Cancer. J Thorac Oncol. 2019;14(3):377-407. https://doi.org/10.1016/j.jtho.2 018.12.005.

24. Cutz E. Neuroendocrine cells of the lung. An overview of morphologic characteristics and development. Exp Lung Res. 1982;3(3-4):185-208. https://doi.org/10.3109/01902148209069653.

25. Li X, Xu H, Kang X, Zhao J, Lin Y, Wang S, et al. Clinical characteristics, treatment and prognosis of 47 non-small cell lung Cancer with neuroendocrine differentiation patients. Zhongguo Fei Ai Za Zhi. 2019;22(8): 507-11. https://doi.org/10.3779/j.issn.1009-3419.2019.08.05.

26. Zhang J, Zheng K, Guo Y, Zhang P, Zhan Z. Research on the relationship between non-small cell lung cancer with neuroendocrine differentiation and the biological characteristics and prognosis. Zhongguo Fei Ai Za Zhi. 2010;13(9):873-6. https://doi.org/10.3779/j.issn.1009-3419.2010.09.07.

27. Rooper LM, Bishop JA, Westra WH. INSM1 is a sensitive and specific marker of neuroendocrine differentiation in head and neck tumors. Am J Surg Pathol. 2018:42(5):665-71. https://doi.org/10.1097/PAS.0000000000001037.

28. Rooper LM, Sharma R, Li QK, Illei PB, Westra WH. INSM1 demonstrates superior performance to the individual and combined use of Synaptophysin, Chromogranin and CD56 for diagnosing neuroendocrine tumors of the thoracic cavity. Am J Surg Pathol. 2017:41(11):1561-9. https:// doi.org/10.1097/PAS.0000000000000916.

29. Sakakibara R, Kobayashi M, Takahashi N, Inamura K, Ninomiya H, Wakejima R, et al. Insulinoma-associated protein 1 (INSM1) is a better marker for the diagnosis and prognosis estimation of small cell lung carcinoma than neuroendocrine phenotype markers such as Chromogranin a, Synaptophysin, and CD56. Am J Surg Pathol. 2020;44(6):757-64. https://doi. org/10.1097/PAS.0000000000001444.

30. Kriegsmann K, Zgorzelski C, Kazdal D, Cremer M, Muley T, Winter H, et al. Insulinoma-associated protein 1 (INSM1) in thoracic tumors is less sensitive but more specific compared with Synaptophysin, Chromogranin a, and CD56. Appl Immunohistochem Mol Morphol. 2020;28(3):237-42. https://doi. org/10.1097/PAl.0000000000000715.

31. Staaf J, Tran L, Soderlund L, Nodin B, Jirstrom K, Vidarsdottir H, et al. Diagnostic value of Insulinoma-associated protein 1 (INSM1) and comparison with established neuroendocrine markers in pulmonary cancers. Arch Pathol Lab Med. 2020;144(9):1075-85. https://doi.org/10 5858/arpa.2019-0250-OA.

32. Minami K, Jimbo N, Tanaka Y, Ogawa H, Hokka D, Nishio W, et al. Insulinoma-associated protein 1 is a prognostic biomarker in pulmonary high-grade neuroendocrine carcinoma. J Surg Oncol. 2020;122(2):243-53. https://doi.org/10.1002/jso.25960.

33. Sauter G. Representativity of TMA studies. Methods Mol Biol. 2010;664:2735. https://doi.org/10.1007/978-1-60761-806-5_3.

\section{Publisher's Note}

Springer Nature remains neutral with regard to jurisdictional claims in published maps and institutional affiliations.

\section{Ready to submit your research? Choose BMC and benefit from:}

- fast, convenient online submission

- thorough peer review by experienced researchers in your field

- rapid publication on acceptance

- support for research data, including large and complex data types

- gold Open Access which fosters wider collaboration and increased citations

- maximum visibility for your research: over $100 \mathrm{M}$ website views per year

At BMC, research is always in progress.

Learn more biomedcentral.com/submissions 